\title{
ISOLASI DAN KARAKTERISASI KOLAGEN DARI KULIT IKAN PATIN (Pangasius sp.)
}

\author{
Pipih Suptijah $^{1)}$, Dini Indriani ${ }^{1)^{*}}$, dan Supriyono Eko Wardoyo ${ }^{2)}$ \\ ${ }^{1)}$ Departemen Teknologi Hasil Perairan, Fakultas Perikanan dan Ilmu Kelautan, \\ Institut Pertanian Bogor, Kampus IPB Dramaga, Jalan Agatis, Bogor 16680 Jawa Barat \\ ${ }^{2)}$ Dosen Program Studi Kimia FMIPA Universitas Nusa Bangsa \\ Jl. KH. Soleh Iskandar KM 4 Cimanggu Tanah Sareal, Bogor 16166 \\ *email : dini_indriani88@yahoo.co.id
}

\section{ABSTRACT \\ Isolation and Characterization of Collagen from the Skin of Catfish (Pangasius sp.)}

\begin{abstract}
Skin of catfish is one of aquatic by-products which could be used as an alternative source of collagen. This research is aimed to isolate and characterize collagen from skin of catfish. Methods of isolation of collagen included three stages, the first was deproteinization using $\mathrm{NaOH}$ solution with concentration of $0.05 \mathrm{M}$; 0.10 M; 0.15 M; 0.20 $M$ for 12 hours, the second was soaking in $\mathrm{CH}_{3} \mathrm{COOH}$ solution with concentration of $0.05 \mathrm{M} ; 0.10 \mathrm{M} ; 0.15 \mathrm{M}$; and $0.20 \mathrm{M}$ for 2 hours, and the third was extraction in water at a temperature of $40^{\circ} \mathrm{C}$ for 2 hours; characterization of collagen was included chemical and physical properties. The results showed that the best extraction method ofcollagen from skin of catfish was soaking the skin in $0.05 \mathrm{M} \mathrm{NaOH}$ solution for 12 hours and soaking the skin in $0.05 \mathrm{M}$ acetic acid for 2 hours. Extraction yields of collagen was 12.15\%. Chemical characteristics included proximate and amino acid composition. Proximate value of collagen consisted of moisture was $6.55 \%$, ash $1.80 \%$, protein $64.74 \%$ and fat $8.85 \%$. The major amino acid composition of collagen were glycine, proline, alanine, arginine and glutamate. Physical characteristics of collagen resulted from FTIR analysis showed amide A, amide B, amide I, amide II and amide III, triple helical structure of the amide I and amide III indicates that the compound produced was collagen; color analysis was $66.39 \%$; thermal analysis showed a melting temperature peak was 154.47 ${ }^{0} \mathrm{C}$ and $\mathrm{pH}$ value was 5.34 .
\end{abstract}

Keywords: Catfish, isolation, characterization, collagen, skin

\begin{abstract}
ABSTRAK
Kulit ikan patin merupakan salah satu limbah hasil perairan yang dapat digunakan sebagai sumber alternatif kolagen. Penelitian ini bertujuan untuk mengisolasi dan karakterisasi kolagen yang diperoleh dari kulit ikan patin. Isolasi kolagen yang dilakukan meliputi tiga tahap, yaitu tahap pertama adalah proses deproteinisasi menggunakan larutan $\mathrm{NaOH}$ dengan konsentrasi, yaitu $0,05 \mathrm{M} ; 0,10 \mathrm{M} ; 0,15 \mathrm{M} ; 0,20 \mathrm{M}$ dan lama waktu perendaman selama 12 jam; tahap kedua, yaitu perendaman dalam larutan $\mathrm{CH}_{3} \mathrm{COOH}$ dengan empat konsentrasi $\mathrm{CH}_{3} \mathrm{COOH}$ yaitu $0,05 \mathrm{M}$; 0,10 M; 0,15 M; dan 0,20 M dan lama waktu perendaman selama 2 jam; dan tahap ketiga, yaitu ekstraksi dengan air pada suhu $40{ }^{\circ} \mathrm{C}$ selama 2 jam; serta karakterisasi kolagen yang dilakukan, meliputi sifat kimia dan fisik. Hasil penelitian menunjukkan bahwa metode ekstraksi kolagen dari kulit ikan patin terbaik diperoleh melalui proses perendaman kulit dalam larutan $\mathrm{NaOH} 0,05 \mathrm{M}$ selama 12 jam dan perendaman kulit dalam asam asetat 0,05 M selama 2 jam. Rendemen serbuk kolagen yang dihasilkan sebesar 12,15\%. Karakteristik kimia meliputi proksimat dan komposisi asam amino. Nilai proksimat kolagen terdiri dari kadar air 6,55 \%, abu 1,80\%, protein 64,74\% dan lemak $8,85 \%$. Komposisi asam amino yang dominan pada kolagen adalah glisina, prolina, alanina, arginina dan glutamat. Karakteristik fisik kolagen yang dihasilkan adalah analisis FTIR menunjukkan adanya gugus amida A, amida B, amida I, amida II dan amida III, struktur triple heliks pada amida I dan amida III mengindikasikan bahwa senyawa yang dihasilkan adalah kolagen; analisis warna yaitu $66,39 \%$; analisis termal yang menunjukkan suhu puncak pelelehan adalah $154,47{ }^{\circ} \mathrm{C}$ dan nilai $\mathrm{pH}$ kolagen yaitu 5,34.
\end{abstract}

Kata kunci : Ikan patin, isolasi, karakterisasi, kolagen, kulit

\section{PENDAHULUAN}

Kolagen memegang peranan cukup penting dalam industri makanan, kosmetik, biomedis, dan farmasi (Chai et al., 2010). Keistimewaan penggunaan kolagen berkaitan dengan karakteristik fisikokimia dari kolagen, diantaranya mudah diserap dalam tubuh, sifat antigenitas rendah, 
afinitas dengan air tinggi, tidak beracun, biocompatible dan biodegradable, relatif stabil, dapat disiapkan dalam berbagai bentuk sesuai kebutuhan, dan mudah dilarutkan dalam air maupun asam (Lee, Singla \& Lee, 2001).

Sumber kolagen yang paling banyak di pasaran umumnya berasal dari kulit dan tulang sapi ataupun babi yang keamanan dan kehalalannya perlu diwaspadai, sehingga diperlukan alternatif sumber kolagen yang aman dan halal. Salah satu biota perairan yang berpotensi sebagai sumber kolagen adalah ikan. Kulit ikan yang di fillet dari berbagai perusahaan industri atau pabrik fillet ikan dianggap sebagai produk limbah, sehingga pemanfaatan kulit ikan sebagai sumber kolagen alternatif tidak hanya dapat mengurangi jumlah limbah industri pengolahan, tetapi sekaligus juga meningkatkan nilai tambah limbah tersebut. Friess (1998) menyatakan bahwa lebih dari $50 \%$ protein ekstra-seluler pada kulit merupakan kolagen.

Salah satu bahan kulit ikan yang berpotensi sebagai sumber kolagen adalah kulit ikan patin. Ikan patin telah dimanfaatkan dalam bentuk produk pangan, namun kulit dari ikan patin tersebut belum dimanfaatkan secara optimal. Dari data statistik Kementerian Kelautan dan Perikanan (KKP) menunjukkan bahwa produksi nasional budidaya ikan patin meningkat dari tahun ke tahun. Pada tahun 2006, produksi ikan patin mencapai 31.490 ton/tahun dan pada tahun 2012 mengalami peningkatan menjadi 651.000 ton/tahun. KKP terus memacu peningkatan produksi ikan patin dari tahun ke tahun dengan target produksi nasional pada tahun 2013 sebesar 1.107.000 ton (Sistem Informasi Diseminasi Data Statistik Kelautan dan Perikanan [SIDATIK], 2013). Hal ini menunjukkan potensi bagi pemanfaatan kulit ikan patin (Pangasius sp.) sebagai sumber kolagen. Penelitian mengenai optimasi metode ekstraksi kolagen dilakukan karena belum ada metode yang baku secara resmi, dan proses pembuatan kolagen, serta karakterisasi fisikokimianya dari kulit ikan patin perlu dilakukan untuk aplikasi sebagai bahan baku kosmetik.

\section{BAHAN DAN METODE}

\section{Bahan dan Alat}

Bahan yang digunakan adalah kulit ikan patin (Pangasius sp.). Kulit ikan patin diperoleh dari limbah Laboratorium Produksi Teknologi Hasil Perairan (THP) Fakultas Perikanan dan Ilmu Kelautan IPB. Bahan-bahan yang digunakan untuk ekstraksi kolagen terdiri dari natrium hidroksida $(\mathrm{NaOH}), \quad$ asam asetat $\left(\mathrm{CH}_{3} \mathrm{COOH}\right)$, akuades, Natrium Klorida $(\mathrm{NaCl})$ dan $\mathrm{pH}$ indikator.

Alat yang digunakan dalam penelitian ini adalah untuk ekstraksi kolagen, diantaranya peralatan gelas merek Pyrex Iwaki, pisau, timbangan digital analitik merek AND, kain kasa, Spektrofotometer UV-VIS merek RS UV2500 Labomed USA, Waterbath Incubator Shaker BT 25 merek Yamato dan freeze dryer merek EYELA FDU-1200. Sementara alat-alat yang digunakan untuk analisis adalah alat untuk analisis proksimat menggunakan Oven merek Yamato DV 41, Tanur merek Yamato FM 38, Soxhlet merek Yamato Scientific Co.,LTD, Destruktor protein merek Tecator dan Destilator protein merek Labentech; alat untuk analisis logam berat menggunakan Atomic Absorption Spectrophotometer (AAS) AA-7000 merek Shimadzu, High Performance Liquid Chromatography (HPLC) merek Waters coorporation USA, pH meter merek Eutech Instruments, Differential Scanning Calorimetry (DSC) merek Shimadzu, Chromameter CR-310 merek Minolta dan Spektrofotometer Fourier Transform Infra Red (FTIR) merek BRUKER TENSOR 37.

\section{Metode}

Penelitian ini dilakukan dalam tiga tahap, yaitu 1) preparasi dan karakterisasi bahan baku kulit ikan patin; 2) optimasi ekstraksi kolagen; dan 3) karakterisasi kolagen, meliputi nilai rendemen, komposisi proksimat, asam amino, gugus fungsi dengan Fourier Transform Infra Red (FTIR), analisis warna, analisis termal dan $\mathrm{pH}$. 


\section{Preparasi dan Karakterisasi Bahan Baku Kulit Ikan patin}

Kulit ikan patin dibersihkan dan dipisahkan dari daging yang masih tersisa menempel pada kulit. Sampel kulit ikan patin tersebut dipotong-potong kemudian disimpan dalam freezer lemari pendingin ($15^{\circ} \mathrm{C}$ ) sampai sampel tersebut akan digunakan. Kulit ikan patin yang akan digunakan dikarakterisasi terlebih dahulu dengan melakukan analisis komposisi kimia kulit (SNI 01-2891-1992) yang meliputi kadar air, abu, protein, lemak dan logam berat $\mathrm{Hg}$ (SNI 01-2354.6-2006), Pb (SNI 012354.7-2006), serta As (SNI 01-4866-1998).

\section{Optimasi Ekstraksi Kolagen \\ (Modifikasi dari Singh, Benjakul, Maqsood \& Kishimura, 2011)}

Ekstraksi kolagen dilakukan dengan tiga tahap, yaitu deproteinisasi menggunakan larutan natrium hidroksida $(\mathrm{NaOH})$, perendaman dalam larutan asam asetat $\left(\mathrm{CH}_{3} \mathrm{COOH}\right)$, dan ekstraksi dengan air. Tahap pertama adalah proses deproteinisasi, yaitu perendaman kulit dalam larutan $\mathrm{NaOH}$ dengan tujuan untuk menghilangkan protein non kolagen. Rasio antara kulit dan larutan $\mathrm{NaOH}$ adalah $1: 10$ (b/v). Pada tahap ini digunakan empat variasi konsentrasi $\mathrm{NaOH}$ yaitu $0,05 \mathrm{M} ; 0,10$ $\mathrm{M} ; 0,15 \mathrm{M} ; 0,20 \mathrm{M}$ dengan lama waktu perendaman selama 12 jam. Larutan $\mathrm{NaOH}$ sisa hasil perendaman kulit yang dihasilkan diuji kandungan protein secara kuantitatif dengan uji biuret (Apriyantono, Fardiaz, Puspitasari, Yasni \& Budiyanto., 1989) dan Bovine Serum Albumin (BSA) sebagai standar serta untuk menentukan konsentrasi $\mathrm{NaOH}$ dan lama waktu perendaman terbaik.

Kulit hasil proses deproteinisasi dengan perendaman konsentrasi $\mathrm{NaOH}$ terbaik dicuci dengan akuades sampai mencapai $\mathrm{pH}$ netral sebelum dilanjutkan pada tahap kedua yaitu hidrolisis dengan perendaman kulit dalam larutan $\mathrm{CH}_{3} \mathrm{COOH}$. Pada tahap ini digunakan empat variasi konsentrasi $\mathrm{CH}_{3} \mathrm{COOH}$, yaitu $0,05 \mathrm{M} ; 0,10$ $\mathrm{M} ; 0,15 \mathrm{M}$; dan $0,20 \mathrm{M}$ dengan lama waktu perendaman selama 2 jam. Rasio antara kulit dengan larutan $\mathrm{CH}_{3} \mathrm{COOH}$ adalah 1:10 (b/v). Parameter uji yang digunakan pada tahap ini adalah pengukuran Derajat Pengembangan
(DP) dari kulit dan uji kelarutan kolagen dalam larutan asam asetat $\left(\mathrm{CH}_{3} \mathrm{COOH}\right)$ dengan menggunakan natrium klorida (NaCl) $5 \mathrm{M}$.

Kulit hasil perendaman larutan $\mathrm{CH}_{3} \mathrm{COOH}$ dengan perlakuan terbaik dicuci dengan akuades sampai mencapai $\mathrm{pH}$ netral sebelum dilanjutkan pada tahap ketiga yaitu ekstraksi dengan air pada suhu $40{ }^{\circ} \mathrm{C}$ selama 2 jam dengan rasio antara kulit dan air adalah 1:1 (b/v). Hasil ekstraksi berupa kolagen larut air, selanjutnya dikeringkan dengan menggunakan freeze dryer untuk memperoleh kolagen dalam bentuk serbuk.

\section{Karakterisasi Kolagen}

Tahap ini bertujuan untuk mendapatkan karakteristik kolagen yang dihasilkan dari perlakuan terbaik pada penelitian tahap ketiga yang mencakup karakteristik kimia maupun fisik. Karakteristik kimia meliputi analisis proksimat (SNI 01-2891-1992) dan jenis asam amino (AOAC, 1995), sedangkan karakteristik fisik yang diukur antara lain gugus fungsi dengan menggunakan spektrofotometer FTIR (Muyonga, Cole, \& Duodu, 2004b), analisis warna (Chromameter Minolta) (Gaurav, 2003), analisis termal (Martianingsih dan Atmaja, 2009), dan pH (AOAC, 2005).

\section{Rancangan Percobaan dan Analisis Data (Steel dan Torrie, 1993)}

Rancangan yang digunakan untuk tahap perendaman dalam larutan $\mathrm{NaOH}$ adalah Rancangan Acak Lengkap Faktorial (RALF) dengan dua faktor yaitu konsentrasi larutan $\mathrm{NaOH}$ sebanyak 4 variasi $(0,05$; 0,$10 ; 0,15$; dan $0,20 \mathrm{M}$ ) dan faktor lama waktu perendaman dengan 6 variasi $(2 ; 4 ; 6$; 8; 10; dan 12 jam). Perlakuan merupakan kombinasi antara konsentrasi $\mathrm{NaOH}$ dengan waktu perendaman. Rancangan yang digunakan untuk tahap perendaman dalam larutan $\mathrm{CH}_{3} \mathrm{COOH}$ adalah Rancangan Acak Lengkap (RAL). Perlakuan merupakan kombinasi antara konsentrasi $\mathrm{CH}_{3} \mathrm{COOH}$ dengan waktu perendaman. Konsentrasi $\mathrm{CH}_{3} \mathrm{COOH}$ sebanyak 4 variasi $(0,05 ; 0,10$; 0,15; dan 0,20 M) dan faktor lama waktu perendaman selama 2 jam. Semua perlakuan dilakukan sebanyak 3 kali ulangan. Data 
yang diperoleh dianalisis dengan analisis ragam (ANOVA), dan apabila ada beda nyata dilanjutkan dengan uji Duncan's Multiple Range Test (DMRT) pada taraf kepercayaan $95 \%$.

\section{HASIL DAN PEMBAHASAN}

\section{Preparasi dan Karakteristik Bahan Baku Kulit Ikan patin}

Kulit ikan patin yang digunakan pada penelitian ini diperoleh dari limbah Laboratorium Produksi Teknologi Hasil Perairan (THP) Fakultas Perikanan dan Ilmu Kelautan IPB, dengan bobot ikan rata-rata 500 - 600 gram/ekor. Sampel kulit ikan patin yang diperoleh kemudian dibersihkan dan dipisahkan dari daging yang masih tersisa menempel pada kulit. Sampel kulit ikan patin tersebut dipotong-potong, dikemas dalam plastik kemudian disimpan dalam freezer sampai sampel tersebut akan digunakan pada tahap selanjutnya. Karakteristik bahan baku merupakan sifat penting untuk mengetahui potensi yang terdapat pada bahan tersebut.

Karakteristik bahan baku dapat diketahui dengan melakukan analisis komposisi kimia. Analisis komposisi kimia kulit ikan patin yang dilakukan pada penelitian ini, meliputi kadar air, kadar abu, kadar lemak, kadar protein dan logam berat $(\mathrm{Hg}, \mathrm{Pb}$ dan $\mathrm{As})$. Analisis komposisi kimia kulit ini dilakukan dengan tujuan untuk menilai kelayakan awal dari kulit ikan patin sebagai bahan baku pembuatan kolagen. Hasil analisis komposisi kimia proksimat kulit ikan patin dan berbagai catfish lain dapat dilihat pada Tabel 1.

Kadar air yang terkandung dalam kulit ikan patin sebesar $65,59 \%$. Kadar air ini paling tinggi bila dibandingkan dengan jenis catfish lainnya (Tabel 1), namun nilai kadar air ini masih berada dalam kisaran kadar air kulit ikan pada umumnya, sehingga dapat dikatakan kulit ikan patin masih dalam kondisi cukup segar.

Kadar abu kulit ikan patin yang dihasilkan sebesar 0,19\% hampir sama dengan kadar abu Pangasianodon gigas sebesar $0,25 \%$ dan $P$. hypophthalmus sebesar $0,23 \%$, namun sedikit lebih rendah dibandingkan dengan Pangasius sutchi sebesar $0,73 \%$ (Thitipramote and Rawkdkuen, 2011; See, Hong, Wan \& Babji, 2010). Kadar abu yang rendah kurang dari 0,5\% merupakan bahan baku yang memiliki kualitas yang baik untuk pembuatan kolagen dan gelatin, karena dengan proses demineralisasi dapat mengurangi kadar abu yang dihasilkan (See et al., 2010).

Tabel 1. Komposisi Kimia Proksimat Kulit Ikan Patin (Pangasius sp.) dan Berbagai Catfish Lainnya

\begin{tabular}{clcccc}
\hline No & Analisis & $\begin{array}{c}\text { Nilai }(\%)^{1} \\
\text { Hasil penelitian }\end{array}$ & $\begin{array}{c}\text { Nilai }(\%)^{2} \\
\text { Referensi }\end{array}$ & $\begin{array}{c}\text { Nilai }(\%)^{3} \\
\text { Referensi }\end{array}$ & $\begin{array}{c}\text { Nilai }(\%)^{4} \\
\text { Referensi }\end{array}$ \\
\hline 1 & Air & 65,59 & 39,24 & 64,86 & 51,85 \\
2 & Abu & 0,19 & 0,73 & 0,25 & 0,23 \\
3 & Lemak & 2,69 & 10,65 & 2,69 & 20,24 \\
4 & Protein & 30,28 & 18,96 & 34,03 & 27,26 \\
\hline
\end{tabular}

Keterangan : ${ }^{1}$ Data Pribadi (Pangasius sp.); ${ }^{2}$ See et al. (2010) (P. sutchi); ${ }^{3}$ Thitipramote \& Rawkdkuen (2011) (P. gigas); ${ }^{4}$ Thitipramote \& Rawkdkuen (2011) (P. hypophthalmus)

Tabel 2. Komposisi Kimia Logam Berat Kulit Ikan patin (Pangasius sp.)

\begin{tabular}{clcccc}
\hline No & Parameter uji & Satuan & Nilai & Keterangan & Syarat SNI 7387-2009 \\
\hline 1 & Merkuri $(\mathrm{Hg})$ & $\mu \mathrm{g} / \mathrm{kg}$ & $-11,375$ & Ttd & $0,5 \mathrm{mg} / \mathrm{kg}$ \\
2 & Timbal $(\mathrm{Pb})$ & $\mathrm{mg} / \mathrm{kg}$ & $-0,422$ & Ttd & $0,3 \mathrm{mg} / \mathrm{kg}$ \\
3 & Arsen $(\mathrm{As})$ & $\mu \mathrm{g} / \mathrm{kg}$ & $-11,714$ & Ttd & $0,1 \mathrm{mg} / \mathrm{kg}$ \\
\hline
\end{tabular}

Keterangan :

ttd $\quad:$ tidak terdeteksi

Limit Deteksi Hg $<0,002 \mathrm{mg} / \mathrm{kg} ; \mathrm{Pb}<0,005 \mathrm{mg} / \mathrm{kg}$; dan As $<0,002 \mathrm{mg} / \mathrm{kg}$ 
Hasil pengujian menunjukkan bahwa kulit ikan patin memiliki kadar lemak sebesar 2,69\%. Kadar lemak ini menunjukkan hasil yang sama dengan ikan $P$. gigas, yaitu sebesar $2,69 \%$. Kadar lemak ini paling rendah bila dibandingkan dengan jenis catfish lain, namun jauh lebih tinggi dibandingkan dengan kulit ikan cucut $(0,16 \%)$ (Mahardika, 2013). Kandungan lemak pada kulit ikan patin yang cukup tinggi ini mengindikasikan perlunya optimasi proses pretreatment kulit untuk menghilangkan lemak dalam kulit ikan, sehingga dapat meningkatkan kualitas kolagen yang dihasilkan. Shon, Ji-Hyun, Hwang \& Jong-Bang (2011) menyatakan bahwa keberadaan lemak dan mineralmineral lainnya akan mengganggu efektivitas kolagen dalam aplikasinya pada berbagai produk.

Kandungan protein kulit ikan patin yang dihasilkan adalah sebesar 30,29\%. Nilai kadar protein ini sedikit lebih rendah dibandingkan dengan $P$. gigas $(34,04 \%)$ dan lebih tinggi bila dibandingkan dengan $P$. sutchi $(18,96 \%)$ dan $P$. hypophthalmus (27,26\%) (See et al., 2010; Thitipramote and Rawkdkuen, 2011). Kandungan protein kulit ikan patin yang cukup tinggi ini memungkinkan untuk digunakan sebagai bahan baku kolagen. Hasil komposisi kimia yang ditunjukkan pada Tabel 3 berbeda-beda antara jenis catfish. Perbedaan tersebut dapat disebabkan oleh perbedaan spesies, umur, habitat, jenis pakan dan preparasi bahan (Songchotikunpan, Tattiyakul \& Supaphol, 2008).

Analisis kandungan logam berat juga merupakan analisis komposisi kimia yang penting. Analisis logam berat pada kulit ikan patin dilakukan agar produk kolagen yang dihasilkan terjamin keamanan dari cemaran logam. Keberadaan logam berat, misalnya merkuri $(\mathrm{Hg})$, timbal $(\mathrm{Pb})$ dan arsen $(\mathrm{As})$ dalam bahan pangan dapat membahayakan kesehatan jika jumlahnya melebihi ambang batas yang ditentukan. Kandungan logam berat untuk ikan dan hasil olahannya yang ditetapkan oleh SNI 7387-2009 adalah 0,3 $\mathrm{mg} / \mathrm{kg}(\mathrm{Pb}) ; 0,5 \mathrm{mg} / \mathrm{kg}(\mathrm{Hg}) ;$ dan $0,1 \mathrm{mg} / \mathrm{kg}$ (As). Berdasarkan hasil pengujian yang dilakukan, kandungan logam berat $\mathrm{Hg}, \mathrm{Pb}$ dan As pada kulit ikan patin dapat dilihat pada Tabel 2 dan hasil tersebut menunjukkan bahwa logam berat $\mathrm{Hg}, \mathrm{Pb}$ dan As pada kulit ikan patin tidak terdeteksi, artinya kulit ikan patin tersebut sangat sedikit sekali mengandung logam berat $\mathrm{Hg}$, $\mathrm{Pb}$ maupun As. Dengan kata lain, kandungan logam-logam tersebut berada di bawah nilai ambang batas dan di bawah limit deteksi alat, sehingga kulit ikan patin aman untuk digunakan sebagai sumber bahan baku kolagen.

\section{Optimasi Ekstraksi Kolagen}

Pembuatan kolagen dari kulit ikan patin terbagi dalam dua tahap, yaitu pretreatment (perendaman kulit dalam larutan $\mathrm{NaOH}$ yang dilanjutkan dengan perendaman kulit dalam asam asetat) dan ekstraksi dengan air. Optimasi pada tahap perendaman kulit dalam larutan $\mathrm{NaOH}$ adalah untuk mendapatkan perlakuan kombinasi konsentrasi $\mathrm{NaOH}$, dan waktu perendaman terbaik dalam menghilangkan protein non kolagen pada kulit ikan. Optimasi pada tahap perendaman asam asetat adalah untuk mendapatkan konsentrasi terbaik terhadap DP kulit dengan tingkat kehilangan kolagen yang rendah.

\section{Perendaman Kulit dalam Larutan $\mathrm{NaOH}$}

Isolasi kolagen atau pembuatan kolagen diawali dengan perlakuan deproteinisasi, yaitu penghilangan protein non kolagen menggunakan larutan alkali. Zhou dan Regenstein (2005) menyatakan contoh dari larutan alkali yang dapat digunakan untuk menghilangkan protein non kolagen, yaitu $\mathrm{NaOH}$ dan $\mathrm{Ca}(\mathrm{OH})_{2}$. Perendaman dalam alkali juga dapat menghilangkan keberadaan lemak pada bahan. Larutan yang digunakan pada penelitian ini, yaitu $\mathrm{NaOH}$ dengan empat variasi konsentrasi berbeda 0,05: 0,10; 0,15 ; dan 0,20 M. Penggunaan larutan basa pada pretreatment kulit lebih efektif dalam proses pengeluaran protein non kolagen dan hanya menyebabkan tingkat kehilangan kolagen yang rendah dibandingkan dengan penggunaan larutan asam (Zhou dan Regenstein, 2005). Hasil pengamatan kandungan protein dari larutan $\mathrm{NaOH}$ sisa perendaman kulit (Gambar 1). 


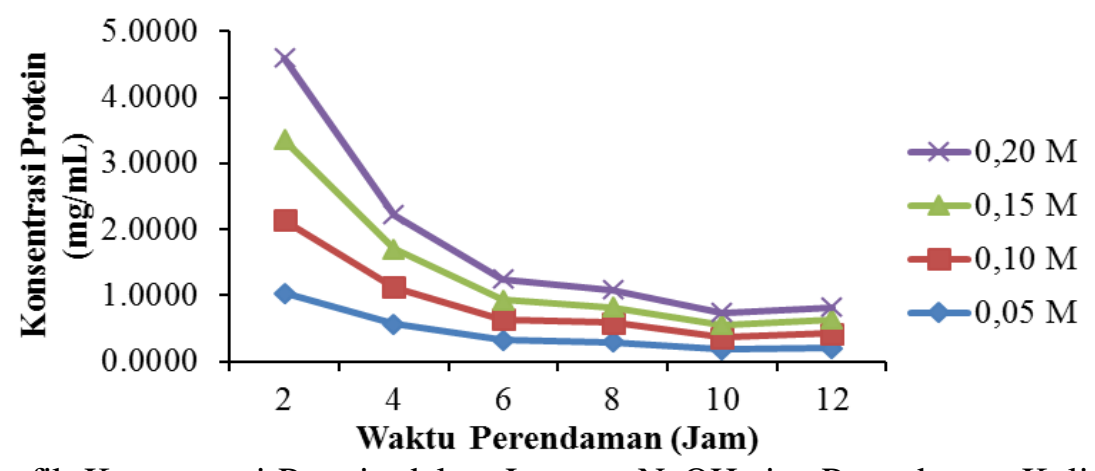

Gambar 1. Grafik Konsentrasi Protein dalam Larutan $\mathrm{NaOH}$ sisa Perendaman Kulit Ikan Patin dengan Kombinasi Perlakuan Konsentrasi $\mathrm{NaOH}$ dan Waktu Perendaman

Kandungan protein dari larutan $\mathrm{NaOH}$ sisa perendaman kulit untuk setiap perlakuan kombinasi konsentrasi $\mathrm{NaOH}$ dengan lama waktu perendaman 2 jam, menunjukkan kandungan protein yang tinggi dan nilai kandungan protein semakin menurun seiring penambahan waktu perendaman. Hal ini menunjukkan bahwa protein non kolagen yang terkandung dalam kulit ikan sudah banyak dilepaskan dengan pelarut basa pada 2 jam pertama perendaman, sehingga jumlah protein non kolagen dalam kulit semakin berkurang yang ditunjukkan dengan semakin kecilnya nilai konsentrasi protein dalam larutan $\mathrm{NaOH}$ sisa perendaman kulit pada pengamatan berikutnya.

Perlakuan pada setiap konsentrasi dengan waktu perendaman 12 jam menunjukkan nilai konsentrasi protein yang cenderung meningkat kembali dari waktu perendaman sebelumnya. Hal ini mengindikasikan bahwa sebagian kolagen dalam kulit mulai terlarut dalam larutan $\mathrm{NaOH}$. Hal ini diduga terjadi karena kelebihan konsentrasi $\mathrm{OH}^{-}$yang mengakibatkan terputusnya sebagian ikatan kovalen dalam struktur kolagen. Hal ini selaras dengan pendapat Jaswir, Monsur \& Salleh (2011) yang menyatakan bahwa $\mathrm{NaOH}$ memiliki peranan dalam pemisahan untaian dari batang-batang serat kolagen. Yoshimura, Terashima, Hozan \& Shirai (2000) melaporkan bahwa basa menyerang terutama wilayah teleopeptida dari struktur kolagen selama proses pretreatment, sehingga dapat menyebabkan kelarutan kolagen.
Hasil analisis ragam (ANOVA) kandungan protein larutan $\mathrm{NaOH}$ sisa perendaman kulit menunjukkan bahwa konsentrasi $\mathrm{NaOH}$, waktu perendaman, dan kombinasi perlakuan konsentrasi $\mathrm{NaOH}$ dan waktu perendaman berpengaruh nyata terhadap kandungan protein pada larutan $\mathrm{NaOH}$ sisa perendaman kulit. Hasil uji lanjut DMRT 5\% menunjukkan bahwa perlakuan terbaik untuk menghilangkan protein non kolagen pada kulit ikan patin adalah perendaman kulit dalam larutan $\mathrm{NaOH} 0,05$ M selama 10 jam. Hasil ini selaras dengan penelitian yang dilakukan Zhou dan Regenstein (2005) yang menunjukkan bahwa protein non kolagen dapat dihilangkan dengan perendaman dalam larutan $\mathrm{NaOH}$ dengan konsentrasi 0,01 $\mathrm{mol} / \mathrm{L}$ dan $0,1 \mathrm{~mol} / \mathrm{L}$. Peningkatan konsentrasi $\mathrm{OH}^{-}$di atas $0,1 \mathrm{~mol} / \mathrm{L}$ tidak memberikan pengaruh terhadap penghilangan protein non kolagen.

\section{Perendaman Kulit dalam Larutan Asam Asetat}

Pada tahap kedua dilakukan perendaman kulit dalam larutan asam asetat. Kulit hasil perendaman larutan $\mathrm{NaOH}$ dengan perlakuan terbaik pada tahap sebelumnya yaitu konsentrasi $0,05 \quad \mathrm{M}$ $\mathrm{NaOH}$ selama 10 jam, kemudian dilanjutkan pada tahap ini dengan melakukan perendaman dalam larutan asam asetat. Kulit yang digunakan dicuci dengan akuades sampai mendekati $\mathrm{pH}$ netral. Pencucian bertujuan untuk mengurangi sisa basa yang masih menempel pada kulit, sehingga tidak mempengaruhi terhadap $\mathrm{pH}$ larutan asam 
asetat yang akan digunakan pada tahap selanjutnya.

Pretreatment asam diperlukan untuk mengubah struktur serat kolagen, sehingga akan mempermudah proses ekstraksi pada tahap selanjutnya. Perendaman dalam asam menyebabkan terjadinya penggembungan kulit (swelling) yang diakibatkan masuknya air ke dalam serat kolagen. Masuknya air ke dalam serat kolagen disebabkan terjadinya gaya elektrostatik antara gugus polar pada serat kolagen dengan $\mathrm{H}^{+}$dari asam, atau terbentuknya ikatan hidrogen antara gugus non polar pada serat kolagen dengan $\mathrm{H}^{+}$dari asam (Jaswir et al., 2011). Pembengkakan ini penting karena dapat mendukung rusaknya struktur serat kolagen, melalui terganggunya ikatan non kovalen dan pada akhirnya mempermudah ekstraksi dan meningkatkan kelarutan kolagen.

Hasil pengamatan terhadap Derajat Pengembangan (DP) kulit hasil perendaman dalam larutan asam asetat pada konsentrasi yang berbeda dan waktu perendaman selama 2 jam dapat dilihat pada Gambar 2. Derajat pengembangan kulit mengalami peningkatan dengan semakin tingginya konsentrasi asam asetat. Hal ini menunjukkan bahwa semakin tinggi konsentrasi asam asetat yang digunakan, mengakibatkan semakin banyak jumlah air yang dapat diserap oleh kulit sehingga serat kolagen menjadi lebih mudah untuk dipisahkan dan akan memudahkan proses ekstraksi kolagen pada tahap selanjutnya.

Hasil analisis ragam (ANOVA) derajat pengembangan kulit menunjukkan bahwa konsentrasi asam asetat berpengaruh nyata terhadap DP kulit. Hasil uji DMRT
5\% menunjukkan bahwa perlakuan konsentrasi asam terbaik untuk menghasilkan derajat pengembangan kulit yang tinggi adalah $0,20 \mathrm{M}$.

Hasil uji kelarutan kolagen menggunakan larutan $\mathrm{NaCl} \quad 5 \quad \mathrm{M}$ menunjukkan bahwa perlakuan dengan menggunakan konsentrasi asam asetat 0,20 $\mathrm{M}$ mengalami tingkat kelarutan yang lebih tinggi dibandingkan perlakuan konsentrasi asam asetat $0,05 \mathrm{M}$ dan $0,10 \mathrm{M}$; namun sedikit lebih rendah dibandingkan dengan konsentrasi $\mathrm{NaCl}$ 0,15 M (Tabel 3). Hal ini mengindikasikan dengan perlakuan konsentrasi asam asetat $0,20 \mathrm{M}$ sebagian kolagen pada kulit sudah banyak terekstrak dalam asam, sehingga dikhawatirkan akan menurunkan rendemen kolagen yang dihasilkan.

DP kulit pada konsentrasi asam asetat $0,05 \mathrm{M}$ dan $0,10 \mathrm{M}$ menunjukkan hasil yang tidak berbeda nyata, tetapi berbeda nyata dengan konsentrasi $0,20 \mathrm{M}$. Tingkat kelarutan kolagen pada asam asetat 0,20 M lebih tinggi dibandingkan dengan konsentrasi asam asetat $0,05 \mathrm{M}$ dan $0,10 \mathrm{M}$. Berdasarkan hal tersebut, maka untuk tahap ini dipilih perlakuan terbaik perendaman kulit dalam asam asetat $0,05 \mathrm{M}$ dan lama waktu perendaman 2 jam dengan derajat pengembangan kulit mencapai $612,816 \%$.

\section{Ekstraksi dengan Air}

Kulit hasil perendaman dalam larutan asam asetat dengan perlakuan terbaik, yaitu $0,05 \mathrm{M}$ selama 2 jam, dilanjutkan pada tahap ketiga, yaitu ekstraksi dengan air. Kulit dicuci dengan akuades sampai pH mendekati netral.

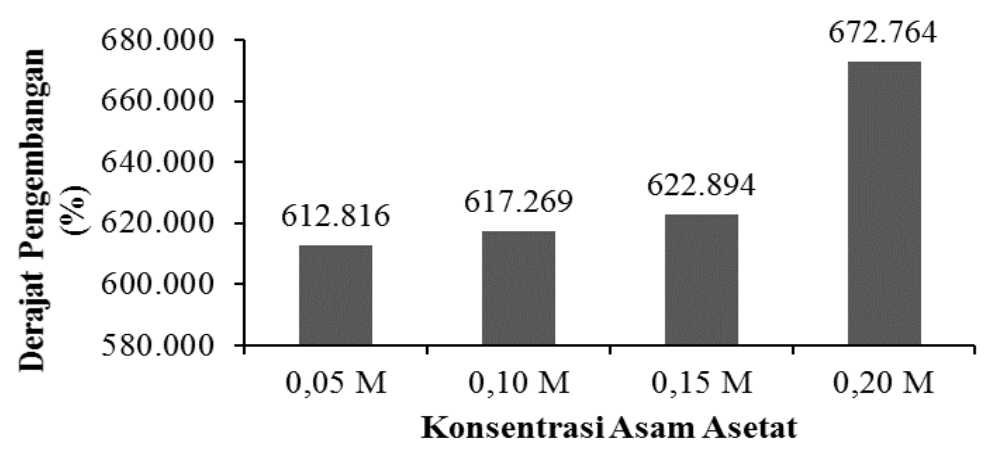

Gambar 2. Grafik DP kulit Ikan patin dengan Perlakuan Konsentrasi dan Lama Waktu Perendaman Asam Asetat 
Tabel 3. Kelarutan Kolagen dalam Larutan Asam Asetat selama 2 Jam

\begin{tabular}{ccc}
\hline No & Konsentrasi asam asetat $(\mathrm{M})$ & Kelarutan Kolagen $(\mathrm{g})$ \\
\hline 1 & 0,05 & 0,053 \\
2 & 0,10 & 0,065 \\
3 & 0,15 & 0,081 \\
4 & 0,20 & 0,072 \\
\hline
\end{tabular}

Tabel 4. Rendemen Kolagen Kulit Ikan patin dan beberapa Kulit Ikan lainnya

\begin{tabular}{clc}
\hline No & \multicolumn{1}{c}{ Sumber Kolagen } & Rendemen \% (bb) \\
\hline 1 & Kulit Ikan patin (Pangasius sp.) & 12,15 \\
2 & ASC Kulit Ikan patin Siam $^{1}$ & 5,10 \\
3 & PSC Kulit Ikan patin Siam & \\
4 & Kulit Ikan Cobia (Rachycentron canadum) $^{2}$ & 7,70 \\
\end{tabular}

Keterangan: ${ }^{1}$ Singh et al., 2011); ${ }^{2}$ (Ariesta, 2014)

Ekstraksi kulit dilakukan dengan air yaitu akuabides, dengan perbandingan kulit dan air yaitu 1:1 dengan menggunakan suhu $40{ }^{\circ} \mathrm{C}$ selama 2 jam. Proses pemanasan kulit dalam air hangat menyebabkan berlanjutnya kerusakan ikatan hidrogen dan kovalen yang sebelumnya sudah berlangsung selama proses perendaman asam asetat. GomézGuillén et al. (2011) menyatakan bahwa proses kerusakan ikatan hidrogen dan kovalen akibat pemanasan kolagen meyebabkan terganggunya kestabilan struktur triple heliks kolagen, sehingga terjadi perubahan bentuk menjadi gulungan dan akhirnya kolagen terdegradasi menjadi gelatin yang larut air. Pemilihan suhu $40{ }^{\circ} \mathrm{C}$ dilakukan dengan tujuan untuk menghindari terjadinya degradasi kolagen menjadi gelatin selama ekstraksi berlangsung. Hal ini didasarkan pada pendapat Karim dan Bhat (2009) yang menyatakan bahwa suhu $40{ }^{\circ} \mathrm{C}$ merupakan suhu transisi perubahan heliks menjadi bentuk gulungan yang mengarah pada pembentukan gelatin yang larut. Hal ini juga diperkuat oleh hasil penelitian Kolodziejska et al. 2008 yang menunjukkan bahwa degradasi kolagen menjadi gelatin terjadi di atas suhu $45{ }^{0} \mathrm{C}$. Hasil ekstraksi kulit dengan air berupa kolagen larut air, kemudian dikeringkan dengan Freeze dryer sehingga diperoleh kolagen dalam bentuk serbuk.

\section{Karakterisasi Kolagen}

Karakteristik kolagen merupakan sifat penting untuk mengetahui potensi yang terdapat pada kolagen tersebut. Kolagen yang dihasilkan dari perlakuan terbaik pada penelitian tahap sebelumnya dikarakterisasi baik sifat kimia maupun fisik. Karakterisasi kolagen yang dilakukan meliputi nilai rendemen, proksimat, jenis asam amino, gugus fungsi dengan FTIR, analisis warna, analisis termal dan $\mathrm{pH}$.

Tabel 5. Komposisi Kimia Kolagen Kulit Ikan patin dan beberapa Kulit Ikan lain

\begin{tabular}{clccc}
\hline No & Analisis & $\begin{array}{c}\text { Nilai }(\%)^{1} \text { Hasil } \\
\text { penelitian }\end{array}$ & $\begin{array}{c}\text { Nilai }(\%)^{2} \\
\text { Referensi }\end{array}$ & $\begin{array}{c}\text { Syarat mutu kolagen } \\
\text { SNI 8076:2014 }\end{array}$ \\
\hline 1 & Air & 6,55 & 7,01 & $\leq 12$ \\
2 & Abu & 1,80 & 3,38 & $\leq 1,0$ \\
3 & Protein & 64,74 & 86,40 & $\geq 75$ \\
4 & Lemak & 8,85 & 0,35 & - \\
\hline
\end{tabular}

Keterangan : ${ }^{1}$ Data Pribadi (Pangasius sp.); ${ }^{2}$ Shon et al. (2011) kulit ikan skate (Raja kenojei) 


\section{Rendemen Kolagen}

Rendemen merupakan persentase kolagen yang dihasilkan dengan bahan baku awal. Rendemen menunjukkan bagian bahan baku yang dapat dimanfaatkan dan menjadi suatu parameter yang penting untuk mengetahui nilai ekonomis, serta keefektifan suatu bahan atau produk. Hasil penelitian menunjukkan kolagen kulit ikan patin memiliki rendemen yang lebih tinggi dari Acid Soluble Collagen (ASC), Pepsin Soluble Collagen (PSC) ikan patin siam (Singh et al. 2011), dan kulit ikan cobia (Rachycentron canadum) (Tabel 4). Potaros, Raksakulthai, Runglerdkreangkrai \& Worawattanamateekul (2009) menyatakan bahwa perbedaan nilai rendemen pada kolagen yang dihasilkan dapat disebabkan oleh perbedaan metode ekstraksi, konsentrasi larutan untuk menghilangkan protein non kolagen, jenis bahan, suhu dan lama waktu produksi.

\section{Komposisi Proksimat}

Komposisi kimia kolagen

merupakan parameter keefektifan proses deproteinisasi, defatting, demineralisasi, dan ekstraksi pada pembuatan kolagen. Perendaman dalam larutan alkali dan asam bertujuan menghilangkan protein non kolagen, serta komponen lain yaitu lemak dan mineral. Proses ini dilakukan agar diperoleh kandungan protein kolagen yang tinggi. Komposisi kimia kolagen kulit ikan patin dan beberapa kolagen kulit ikan lain disajikan pada Tabel 5 .

Berdasarkan Tabel 5 dapat dilihat bahwa komponen utama kolagen adalah protein dan komponen lainnya berupa air, abu dan lemak dalam jumlah yang sedikit. Kandungan air kolagen kulit ikan patin yang dihasilkan, yaitu 6,55 \% lebih rendah dibandingkan dengan kandungan air kolagen dari kulit ikan skate ( $R$. kenojei) yaitu 7,01 $\%$ dan memenuhi syarat mutu kolagen (SNI 8076:2014) yaitu $\leq 12$. Kandungan protein kolagen kulit ikan patin lebih rendah dibandingkan dengan protein kolagen dari kulit ikan skate ( $R$. kenojei) dan syarat mutu kolagen (SNI 8076:2014). Jamilah, Hartina, Hashim \& Sazil (2013) menyatakan perbedaan kadar protein dapat disebabkan oleh perbedaan metode ekstraksi yang digunakan. Perbedaan yang kurang memenuhi standar mutu kolagen ini pun dapat disebabkan oleh proses pretreatment yg masih kurang efektif. Kadar abu pada kolagen kulit ikan patin lebih rendah dibandingkan dengan kadar abu pada kolagen dari kulit ikan skate ( $R$. kenojei) namun sedikit lebih tinggi dari syarat mutu kolagen (SNI 8076:2014). Kandungan lemak pada kolagen kulit ikan patin lebih tinggi dibandingkan dengan lemak dari kolagen kulit ikan skate ( $R$. kenojei).

Kolagen kulit ikan patin memiliki kandungan lemak yang tinggi dan abu yang sedikit melebihi dari syarat mutu kolagen. Hal ini dapat disebabkan oleh perbedaan komposisi kimia yang terkandung dalam bahan baku kulit dan teknik ekstraksi yang digunakan. Shon et al. (2011) menyatakan bahwa kulit yang memiliki kandungan lemak dan abu yang tinggi memerlukan teknik pemurnian yang berbeda untuk menghasilkan produk kolagen dengan kemurnian yang tinggi. Tingginya nilai kandungan lemak dan abu pada kolagen dari kulit ikan patin yang dihasilkan, dapat disebabkan pada proses pretreatment kulit dengan perendaman dalam larutan basa kurang efektif untuk mereduksi lemak dan mineral-mineral dalam kulit ikan patin.

\section{Asam Amino}

Asam amino merupakan struktur pembentuk protein. Asam amino esensial adalah asam amino yang tidak dapat disintesis oleh tubuh tetapi sangat diperlukan oleh tubuh. Asam amino esensial dalam kolagen diantaranya isoleusin, leusin, lisin, metionin, fenilalanin, treonin, valin dan arginin (Haris, 2008). Kolagen merupakan komponen struktural utama dari jaringan ikat yang meliputi hampir $30 \%$ dari total protein tubuh. Molekul dasar kolagen terbentuk dari tiga rantai polipeptida yang saling berpilin membentuk struktur triple heliks dengan susunan asam amino yang khas yaitu Gly-X-Y, pada posisi $X$ adalah prolin dan posisi $\mathrm{Y}$ adalah hidroksiprolin (Friess, 1998).

Komposisi asam amino penyusun kolagen dapat dilihat pada Tabel 8. Kolagen kulit ikan patin memiliki komposisi asam amino yang paling dominan adalah glisin 
dan prolin yaitu berturut-turut dengan nilai $19,45 \%$ dan $11,78 \%$. Hasil penelitian ini selaras dengan kandungan asam amino kolagen dari kulit ikan striped catfish ( $P$. hypophthalmus) yang paling dominan, yaitu glisin 30,9\% dan prolin 12,0 \% (ASC); serta glisin $31,7 \%$ dan prolin $12,6 \%$ (PSC) (Singh et al. 2011). Nalinanon, Benjakul, Kishimura \& Osako (2011) mengatakan kolagen tipe I mengandung asam amino glisin, alanin, dan prolin dalam jumlah yang tinggi, sedangkan asam amino tirosin dan histidin hanya terdapat dalam jumlah yang sedikit serta tidak mengandung sistin. Keberadaan sistin pada kolagen yang dihasilkan menunjukkan deproteinisasi belum berjalan optimal sehingga memungkinkan adanya keberadaan asam amino sistin. Penelitian ini dapat menggambarkan bahwa ekstrak protein yang dihasilkan dari kulit ikan patin sudah termasuk dalam kolagen karena memiliki komposisi asam amino glisin, alanin dan prolin dalam jumlah yang tinggi.

Tabel 6. Komposisi Asam Amino Kolagen dari Kulit Ikan patin

\begin{tabular}{ccc}
\hline No & Asam Amino & Hasil $(\%)$ \\
\hline 1 & Histidin & 1,45 \\
2 & Serin & 6,40 \\
3 & Arginin & 10,12 \\
4 & Glisin & 19,45 \\
5 & Aspartat & 5,31 \\
6 & Glutamat & 12,17 \\
7 & Threonin & 2,86 \\
8 & Alanin & 11,78 \\
9 & Prolin & 9,95 \\
10 & Sistin & 3,07 \\
11 & Lisin & 2,77 \\
12 & Tirosin & 1,84 \\
13 & Metionin & 0,59 \\
14 & Valin & 4,72 \\
15 & Isoleusin & 1,52 \\
16 & Leusin & 4,15 \\
17 & Fenilalanin & 1,85 \\
\hline
\end{tabular}

\section{Analisis Gugus Fungsi dengan Fourier} Transform Infrared (FTIR)

Analisis FTIR yang dilakukan pada penelitian ini bertujuan memastikan senyawa yang dihasilkan merupakan kolagen berdasarkan gugus-gugus fungsi penyusunnya. Hasil spektrum infrared kolagen disajikan pada Gambar 3, sedangkan karakteristik gugus fungsi kolagen hasil analisis FTIR disajikan pada Tabel 7. Berdasarkan spektrum FTIR kolagen dari kulit ikan patin menunjukkan puncak-puncak serapan pada wilayah serapan amida yang meliputi amida A, amida B, amida I, amida II dan amida III. Puncak serapan amida A yang dimiliki kolagen dari kulit ikan patin terdeteksi pada bilangan gelombang $3407,37 \mathrm{~cm}^{-1}$ yang menunjukkan vibrasi stretching $\mathrm{NH}$. Nagarajan, Benjakul, Prodpran, Songtipya, \& Kishimura (2012) menyatakan bahwa bilangan gelombang normal yang dimiliki amida A, yaitu $3400 \mathrm{~cm}^{-1}-3440 \mathrm{~cm}^{-1}$. Ketika gugus N-H pada peptida dipengaruhi oleh ikatan hidrogen, posisinya akan bergeser ke frekuensi yang lebih rendah. Spektrum FTIR kolagen juga menunjukkan adanya puncak serapan pada bilangan gelombang 2933,24 $\mathrm{cm}^{-1}$ yang mengindikasikan adanya gugus khas kolagen, yaitu amida B. Coates (2000) menyatakan gugus amida B dengan wilayah serapan pada bilangan gelombang $2915 \mathrm{~cm}^{-1}$ - $2935 \mathrm{~cm}^{-1}$ atau $2845 \mathrm{~cm}^{-1}-2865 \mathrm{~cm}^{-1}$. Kong \& Yu (2007) menyatakan bilangan gelombang yang mengindikasikan serapan amida B terbentuk dari asimetrikal stretching $\mathrm{CH}_{2}$.

Bilangan gelombang amida I yang terdeteksi pada kolagen dari kulit ikan patin, yaitu $1640,89 \mathrm{~cm}^{-1}$ yang menunjukkan adanya vibrasi peregangan gugus $\mathrm{C}=\mathrm{O}$. Amida I merupakan gugus fungsi khas yang menyusun kolagen. Kong \& Yu (2007) menyatakan bahwa amida I terdeteksi pada kisaran bilangan gelombang $1600 \mathrm{~cm}^{-1}$ $1690 \mathrm{~cm}^{-1}$. Nilai ini serupa dengan hasil yang diperoleh oleh Singh et al. (2011), ASC kulit ikan stripped catfish memiliki gugus amida I pada bilangan gelombang $1651 \mathrm{~cm}^{-1}$, dan bilangan gelombang pada PSC kulit ikan stripped catfish lebih rendah yaitu, $1649 \mathrm{~cm}^{-1}$. Muyonga et al. (2004b) menyatakan bahwa amida I terdiri dari empat komponen struktur sekunder protein, yaitu $\alpha$-heliks, $\beta$-sheet, $\beta$-turn, dan random coil. Kong \& Yu (2007) mengungkapkan bahwa setiap kom-ponen dari struktur sekunder protein memiliki wilayah serapan 
yang berbeda. Komponen $\alpha$-heliks ditunjukkan pada wilayah serapan bilangan gelombang 1654 dan $1658 \mathrm{~cm}^{-1} ; \beta$-sheet pada 1624 dan $1642 \mathrm{~cm}^{-1} ; \beta$-turn pada 1666 , 1672, 1680, $1688 \mathrm{~cm}^{-1}$; dan random coil pada $1648 \pm 2 \mathrm{~cm}^{-1}$. Berdasarkan hasil bilangan gelombang amida I pada kolagen kulit ikan patin menunjukkan bahwa kolagen yang dihasilkan memiliki struktur $\beta$-sheet. Hal ini mengindikasikan bahwa senyawa molekul yang dihasilkan dari proses ekstraksi dengan air pada suhu $40{ }^{0} \mathrm{C}$ merupakan kolagen dan belum terdegradasi menjadi bentuk gelatin. Gomez-Guillén et al. (2011) menyatakan bahwa denaturasi kolagen akibat proses pemanasan, menyebabkan rantai triple heliks kolagen secara sempurna bertransformasi menjadi rantai tunggal $\alpha$-heliks (gelatin).

Amida II yang merupakan gugus fungsi khas kolagen yang terdeteksi pada bilangan gelombang 1550,28 $\mathrm{cm}^{-1}$. Kong \& $\mathrm{Yu}$ (2007) menyatakan wilayah serapan amida II, yaitu pada kisaran $1480 \mathrm{~cm}^{-1}$ $1575 \mathrm{~cm}^{-1}$. Adanya gugus Amida II menunjukkan adanya gugus $\mathrm{CN}$ stretching dan NH bending. Kong \& Yu (2007) menyatakan Amida III memiliki wilayah serapan $1229 \mathrm{~cm}^{-1}-1301 \mathrm{~cm}^{-1}$. Wilayah serapan kolagen pada bilangan gelombang $1239,46 \mathrm{~cm}^{-1}$ mengindikasikan adanya gugus fungsi amida III yang menunjukkan $\mathrm{CH}$ stretching dan $\mathrm{NH}$ bending. Nilai ini serupa dengan hasil yang diperoleh oleh Singh et al. (2011), ASC kulit ikan stripped catfish memiliki gugus amida III dengan bilangan gelombang $1242 \mathrm{~cm}^{-1}$ dan nilai bilangan gelombang pada PSC kulit ikan stripped catfish lebih tinggi, yaitu $1244 \mathrm{~cm}^{-1}$. Muyonga et al. (2004b) menyatakan bahwa intensitas amida III berkaitan dengan adanya struktur triple heliks. Hal ini berarti bahwa ekstraksi kolagen kulit ikan patin dengan air pada suhu $40{ }^{\circ} \mathrm{C}$ belum mengubah kolagen menjadi gelatin yang ditandai dengan masih adanya struktur triple heliks.

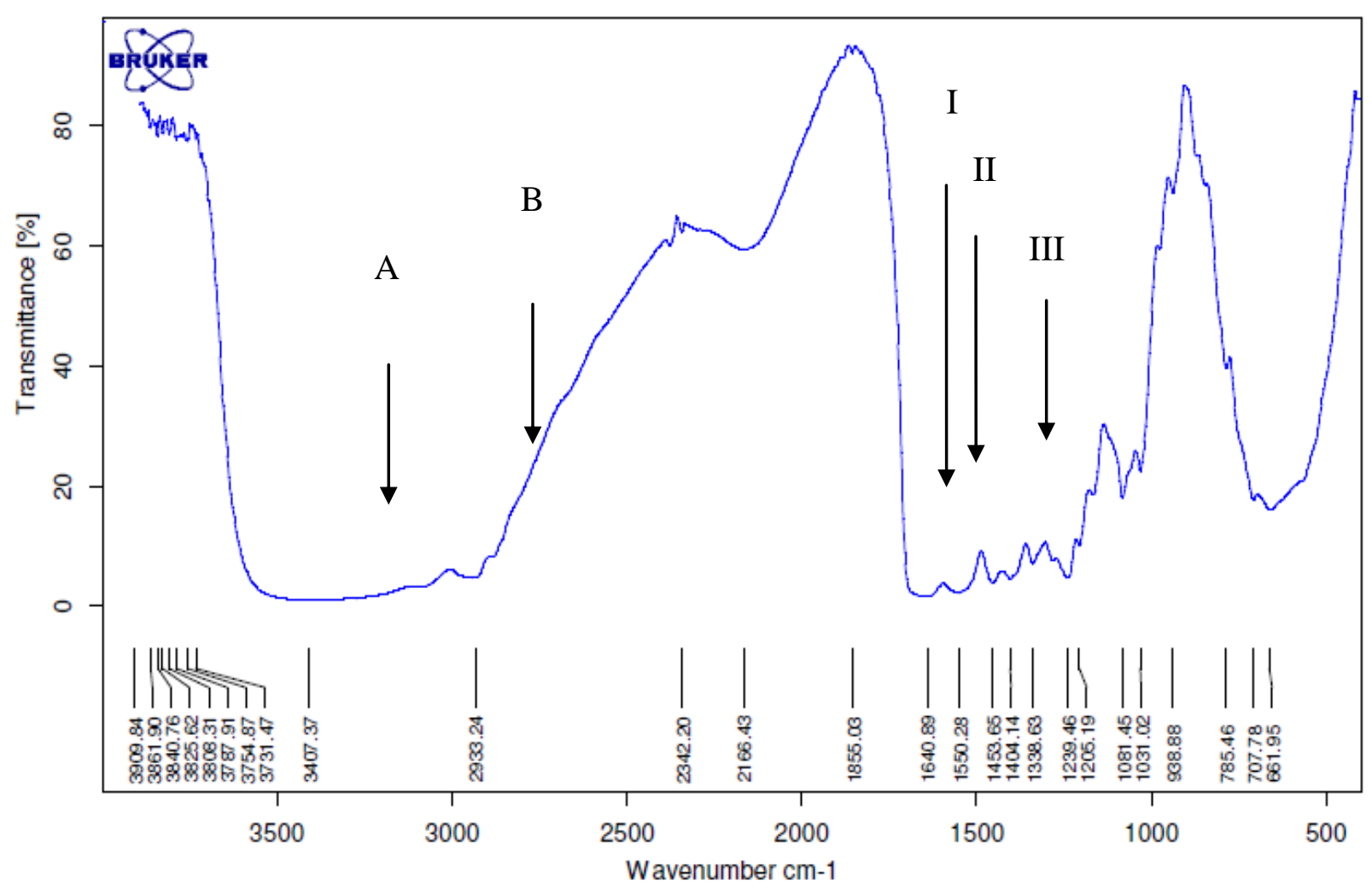

Gambar 3. Spektrum Infrared Kolagen 
Tabel 7. Karakteristik Gugus Fungsi Kolagen Hasil Analisis FTIR

\begin{tabular}{|c|c|c|c|c|c|}
\hline No & Amida & $\begin{array}{l}\text { Bilangan } \\
\text { gelombang } \\
\left(\mathrm{cm}^{-1}\right)\end{array}$ & $\begin{array}{l}\text { Wilayah } \\
\text { serapan } \\
\left(\mathrm{cm}^{-1}\right)\end{array}$ & Keterangan & Referensi \\
\hline 1 & Amida A & 3407,37 & $\begin{array}{l}3300- \\
3500\end{array}$ & Vibrasi stretching $\mathrm{NH}$ & $\begin{array}{l}\text { Muyonga, Cole, \& } \\
\text { Duodu, (2004a) }\end{array}$ \\
\hline 2 & Amida B & 2933,24 & $\begin{array}{l}2915- \\
2935\end{array}$ & $\begin{array}{l}\text { Asimetrimetrikal } \\
\text { stretching } \mathrm{CH}_{2}\end{array}$ & Coates (2000) \\
\hline 3 & Amida I & 1640,89 & $\begin{array}{l}1600- \\
1690\end{array}$ & $\begin{array}{l}\text { Vibrasi stretching } \\
\mathrm{C}=\mathrm{O}\end{array}$ & $\begin{array}{l}\text { Kong dan Yu } \\
\text { (2007) }\end{array}$ \\
\hline 4 & Amida II & 1550,28 & $\begin{array}{l}1480- \\
1575\end{array}$ & $\begin{array}{l}\mathrm{CH} \text { stretching, } \mathrm{NH} \\
\text { bending }\end{array}$ & $\begin{array}{l}\text { Kong dan Yu } \\
\text { (2007) }\end{array}$ \\
\hline 5 & Amida III & 1239,46 & $\begin{array}{l}1229- \\
1301\end{array}$ & $\begin{array}{l}\mathrm{CH} \text { stretching, } \mathrm{NH} \\
\text { bending }\end{array}$ & $\begin{array}{l}\text { Kong dan Yu } \\
\text { (2007) }\end{array}$ \\
\hline
\end{tabular}

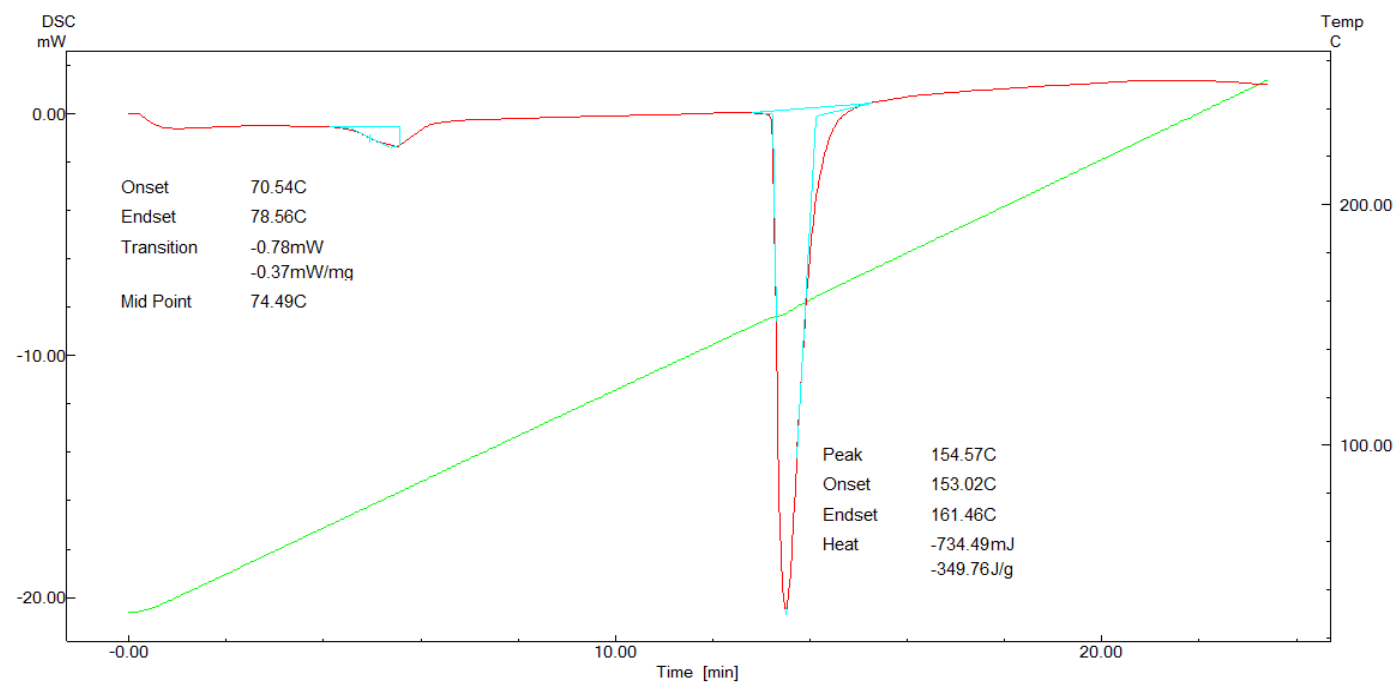

Gambar 4. Kurva Hasil Analisis Termal Kolagen dari Kulit Ikan patin

\section{Analisis Termal}

Analisis termal digunakan untuk memahami sifat termodinamis material, sehingga dapat diketahui sifat material di bawah pengaruh pemanasan atau pendinginan, di bawah atmosfer reduksi atau oksidasi dan di bawah tekanan gas. Analisis termal dengan metode Differential Scanning Calorimetry (DSC) dilakukan dengan mengukur perbedaan aliran panas pada sampel dan standar. Teknik ini biasa digunakan untuk mengukur fase-fase transisi, yaitu transisi gelas ( $\mathrm{Tg}$ ), titik leleh (Tm) dan suhu dekomposisi (Td) pada polimer.

Kurva hasil analisis termal dari kolagen kulit ikan patin dapat dilihat pada Gambar 4. Berdasarkan kurva tersebut, kolagen memiliki transisi gelasi pada suhu $74,49{ }^{\circ} \mathrm{C}$ dan suhu puncak pelelehan terjadi pada $154,47{ }^{\circ} \mathrm{C}$, sedangkan suhu awal dan akhir pelelehan adalah pada suhu $153,00{ }^{\circ} \mathrm{C}$ dan $161,46{ }^{\circ} \mathrm{C}$. Hasil penelitian analisis termal ini sedikit lebih rendah, yaitu 154,47 ${ }^{0} \mathrm{C}$ dibandingkan dengan hasil penelitian Nur'aenah (2013) yang menunjukkan suhu puncak pelelehan kolagen kulit ikan pari terjadi pada suhu $165,88{ }^{\circ} \mathrm{C}$. Perbedaan stabilitas termal dari kolagen ini dapat disebabkan oleh beberapa hal, yaitu komposisi dan susunan asam imino sebagai pembentuk struktur tersier kolagen (Ahmad dan Benjakul, 2010), musim penangkapan dan tingginya komposisi ikatan $1 \alpha$ pada struktur kolagen (Duan et al., 2012), asal bahan baku (Karim dan Bhat, 2009), serta keberadaan garam-garam mineral (KomsaPenkova, Koynova, Kostov \& Tenchov, 1996). 
pH

Hasil pengukuran $\mathrm{pH}$ kolagen kulit ikan patin bersifat asam, yaitu 5,34 pada suhu ruang. Hasil tersebut lebih rendah dibandingkan dengan syarat mutu kolagen SNI 8076:2014 yaitu 6,5-8, namun sedikit lebih tinggi dari $\mathrm{pH}$ kolagen beberapa merk kolagen untuk kosmetik yang dilaporkan Peng, Glattauer, Werkmeister \& Ramshaw (2004) yaitu berkisar antara 3,8 - 4,7, dan hampir mendekati bila dibandingkan dengan $\mathrm{pH}$ kolagen dari sisik ikan yaitu berkisar antar 5,5 - 6,6 (Hartati dan Kurniasari, 2010).

Selain itu, perbedaan nilai $\mathrm{pH}$ kolagen tersebut dapat disebabkan oleh perbedaan jenis dan konsentrasi larutan yang digunakan, baik asam atau basa dan proses penetralan. Kombinasi proses asam dan basa cenderung menghasilkan $\mathrm{pH}$ mendekati netral (Zhou dan Regenstein, 2005). Proses penetralan yang dilakukan akan berpengaruh pada $\mathrm{pH}$ akhir kolagen, karena selain dapat mengurangi sisa-sisa larutan asam atau basa akibat perendaman, juga kemungkinan dapat ditimbulkan dari air yang digunakan untuk menetralkan kolagen tersebut. Air yang digunakan bersifat kurang mendekati netral, sehingga mengakibatkan nilai $\mathrm{pH}$ akhir kolagen yang dihasilkan kurang mendekati $\mathrm{pH}$ netral.

\section{KESIMPULAN}

Berdasarkan penelitian yang sudah dilakukan dapat disimpulkan bahwa:

1. Perlakuan terbaik pada proses pretreatment dalam larutan $\mathrm{NaOH}$ adalah konsentrasi terkecil $0,05 \mathrm{M}$ dengan rasio $1: 10(\mathrm{~b} / \mathrm{v})$ selama $10 \mathrm{jam}$.

2. Perlakuan terbaik pada proses hidrolisis dalam larutan asam asetat adalah konsentrasi terkecil $0,05 \mathrm{M}$ dengan rasio 1:10 (b/v) selama 2 jam, dan ekstraksi dengan air pada suhu $40{ }^{\circ} \mathrm{C}$ dengan rasio 1:1 (b/v) selama 2 jam. Rendemen kolagen yang dihasilkan dari perlakuan terbaik tersebut adalah $12,15 \%$.

3. Karakteristik kimia kolagen dari kulit ikan patin meliputi analisis proksimat dan komposisi asam amino. Proksimat kolagen mengandung air $6,55 \%$, abu $1,80 \%$, protein $64,74 \%$ dan lemak $8,85 \%$; dan komposisi asam amino yang dominan terdapat pada kolagen adalah glisin, prolin, alanin, arginin dan glutamat. Karakteristik fisik kolagen yang dihasilkan adalah analisis FTIR menunjukkan adanya gugus amida A, amida B, amida I, amida II dan amida III, struktur triple heliks pada amida I dan amida III mengindikasikan bahwa senyawa yang dihasilkan adalah kolagen; analisis warna yang menunjukkan derajat putih kolagen kulit ikan patin adalah $66,39 \%$; analisis termal yang menunjukkan suhu puncak pelelehan adalah $154,47{ }^{\circ} \mathrm{C}$ dan nilai $\mathrm{pH}$ kolagen yaitu 5,34 .

\section{DAFTAR PUSTAKA}

Ahmad, M., \& Benjakul, S. (2010). Extraction and characterisation of pepsinsolubilised collagen from the skin of unicorn leatherjacket (Aluterus monocerous). Food Chem, 120, 817824.

Association of Official Analytical Chemist. (1995). Official methods of analysis. Washington, DC: The Association of Official Analytical Chemist. Inc.

Association of Official Analytical Chemist. (2005). Official methods of analysis (18 Edn). Mayland. USA: Association of Official Analytical Chemist Inc.

Apriyantono, A., Fardiaz, D., Puspitasari, N.L., Yasni, S., \& Budiyanto, S. (1989). Analisis pangan. Bogor: IPB Press.

Ariesta, C. (2014). Ekstraksi dan karakterisasi kolagen dari kulit ikan cobia (Rachycentron canadum) (skripsi). Bogor: Departemen Teknologi Hasil Perairan, Fakultas Perikanan dan Ilmu Kelautan, IPB.

Chai, H.J., Li, J.H., Huang, H.N., Li, T.L., Chan, Y.L., Shiau, C.Y., \& Wu1, C.J. (2010). Effects of sizes and conformations of fish-scale collagen 
peptides on facial skin qualities and transdermal penetration efficiency. $J$ Biomed Biotechnol, 2010, 1-9. doi:10.1155/2010/757301.

Coates, J. (2000). Interpretation of infrared spectra, a practical approach. Di dalam: Meyers RA, editor. Encyclopedia of Analytical Chemistry. Chichester: John Wiley \& Sons Ltd.

Duan, R., Zhang, J., Li, J., Zhong, X., Konno, K., \& Wen, H. (2012). The effect of the subunit composition on the thermostability of collagens from the scales of freshwater fish. Food Chem, 135, 127-132.

Friess, W. (1998). Collagen - biomaterial for drug delivery. Eur J Pharm Biopharm, 45, 113-136.

Gaurav, S. (2003). Digital color imaging handbook. CRC Press. ISBN 084930900X.

Gime'nez, B., Turnay, J., Lizarbe, M.A., Montero, P., \& Go'mez-Guillen,M.C. (2005). Use of lactic acid for extraction of fish skin gelatin. Food Hydrocolloid, 19, 941-950

Gómez-Guillén, M.C., Turnay, J., Fernández-Díaz, M.D., Ulmo, N., Lizarbe, M.A., \& Montero, P. (2002). Structural and physical properties of gelatin extracted from different marine species: a comparative study. Food Hydrocolloid, 16, 25-34.

Haris, M.A. (2008). Pemanfaatan limbah tulang ikan nila (Oreochromis niloticus) sebagai gelatin dan pengaruh lama penyimpanan pada suhu ruang (skripsi). Bogor: Departemen Teknologi Hasil Perairan, Fakultas Perikanan dan Ilmu Kelautan, IPB.

Hartati I., \& Kurniasari, L. (2010). Kajian produksi kolagen dari limbah sisik ikan secara ekstrasi enzimatis. Momentum, 6 (1), 33-35.

Jamilah, B., Hartina, M.U., Hashim, D.M., \& Sazili, A.Q. (2013). Properties of collagen from barramundi (Lates calcarifer) skin. International Food Research Journal 20 (2), 835-842.

Jaswir, I., Monsur, H.A., \& Salleh, H.M. (2011). Nano-structural analysis of fish collagen extracts for new process development. Afr J Biotechnol, 10 (81), 18847- 18854.

Karim, A.A., \& Bhat, R. (2009). Fish gelatin: properties, challenges, and prospects as an alternative to mammalian gelatins. Food Hydrocolloid, 23, 563-576.

Komsa-Penkova, R., Koynova, R., Kostov, G., \& Tenchov, B.G. (1996). Thermal stability of calf skin collagen type I in salt solutions. Biochimica et Biophysica Acta, 1297, 171-181.

Kong, J., \& Yu, S. (2007). Fourier transform infrared spectroscopic analysis of protein secondary structures. Acta bioch bioph sin, 39 (8), 549-559.

Lee, C.H., Singla, A., \& Lee, Y. (2001). Biomedical applications of collagen. Int J Pharm, 221, 1-22.

Mahardika, S. (2013). Isolasi dan karakterisasi kolagen nanopartikel dari kulit ikan cucut bambu (Chiloscyllium punctatum) (skripsi). Bogor: Program Studi Teknologi Hasil Perairan, Fakultas Perikanan dan Ilmu kelautan, IPB.

Martianingsih, N., \& Atmaja, L. (2009). Analisis sifat kimia, fisik, dan termal gelatin dari ekstraksi kulit Ikan pari (himantura gerrardi) melalui variasi jenis larutan asam. Prosiding KIMIA FMIPA - ITS.

Muyonga, J.H., Cole, C.G.B., \& Duodu, K.G. (2004a). Characterisation of 
acids soluble collagen from skins of young and adulti Nile perch (Lates niloticus). Food Chemistry 85(1), 8189.

Muyonga, J.H., Cole, C.G.B., \& Duodu, K.G. (2004b). Fourier transform infrared (FTIR) spectroscopic study of acid soluble collagen and gelatin from skins and bones of young and adult Nile perch (Lates niloticus). Food Chem, 86, 325-332.

Nagarajan, M., Benjakul, S., Prodpran, T., Songtipya, P., \& Kishimura, H. (2012). Characteristics and functional properties of gelatin from splendid squid (Loligo formosana) skin as affected by extraction temperatures. Food Hydrocolloids, 29, 389-397.

Nalinanon, S., Benjakul, S., Kishimura, H., \& Osako, K. (2011). Type I collagen from the skin of ornate threadfin bream (Nemipterus hexodon): Characteristics and effect of pepsin hydrolysis. Food Chem, 125, 500-507.

Nur'aenah, N. (2013). Ekstraksi dan karakterisasi kolagen dan nanopartikel kolagen dari kulit ikan pari (Pastinachus solocirostris) sebagai bahan baku kosmetik (tesis). Bogor: Sekolah Pascasarjana, IPB.

Peng, Y., Glattauer, V., Werkmeister, J.A., \& Ramshaw, J.A.M. (2004). Evaluation for collagen products for cosmetic application. J Cosmestic Sci, 55, 327-341.

Potaros, T., Raksakulthai, N., Runglerdkreangkrai, J., \& Worawattanamateekul, W. (2009). Characteristics of collagen from nile tilapia (Oreochromis niloticus) skin isolated by two different methods. Kasetsart Journal, 43, 584-593.

See, S.F., Hong, P.K.L., Wan, A.W.M., \& Babji, A.S. (2010). Physicochemical of gelatins extracted from skin of different freshwater fish species.
International Food Reseacrh Journal, 17, 809-816.

Shon, J., Ji-Hyun, E., Hwang, S.J., \& JongBang, E. (2011). Effect of processing conditions on functional properties of collagen powder from Skate (Raja kenojei) skins. Food Sci Biotechnol, 20 (1), 99-106.

Sistem Informasi Diseminasi Data Statistik Kelautan dan Perikanan. (2013). KKP targetkan produksi patin 11 juta ton. Diperoleh dari www.antaranews.com.

Singh, P., Benjakul, S., Maqsood, S., \& Kishimura, H. (2011). Isolation and characterisation of collagen extracted from the skin of striped catfish (Pangasianodon hypophthalmus). Food Chem, 124, 97-105.

Standar Nasional Indonesia 01-2891-1992. (1992). Cara uji makanan dan minuman. Jakarta: Badan Standarisasi Nasional.

Standar Nasional Indonesia 01-4866.-1998. (1998). Cara uji cemaran arsen dalam makanan. Jakarta: Badan Standarisasi Nasional.

Standar Nasional Indonesia 01-2354.6-2006. (2006a). Cara uji kimia Bagian 6: Penentuan kadar logam berat merkuri (Hg) pada produk perikanan. Jakarta: Badan Standarisasi Nasional.

Standar Nasional Indonesia 01-2354.7-2006. (2006b). Cara uji kimia Bagian 7: Penentuan kadar logam berat timbal $(\mathrm{Pb})$ pada produk perikanan. Jakarta: Badan Standarisasi Nasional.

Standar Nasional Indonesia 7387-2009. (2009). Batas maksimum cemaran logam berat dalam pangan. Jakarta: Badan Standarisasi Nasional.

Standar Nasional Indonesia 8076:2014. (2014). Kolagen Kasar dari Sisik Ikan - Syarat Mutu dan Pengolahan. Jakarta: Badan Standarisasi Nasional. 
Songchotikunpan, P., Tattiyakul, J., \& Supaphol, P. (2008). Extraction and electrospinning of gelatin from fish skin. Int J Biol Macromol, 42, 247255 .

Steel, R.G.D., \& Torrie, J.H. (1993). Prinsip dan Prosedur Statistika, Suatu Pendekatan Biometrik. Sumantri B, penerjemah. Terjemahan dari : Principles and Procedures of Statistics. Jakarta: Gramedia Pustaka Utama.

Thitipramote, N., \& Rawkdkuen,S. (2011). Histological structure and chemical composition of the farmed giant catfish's skin. $J$ of Microsc soc Thai, 4(2), 89-93.

Yoshimura, K., Terashima, M., Hozan, D., \& Shirai, K. (2000). Preparation and dynamic viscoelasticity characterization of alkali-solubilized collagen from shark skin. J Agric Food Chem, 48, 685-690.

Zhou, P., \& Regenstein, J.M. (2005). Effects of alkaline and acid pretreatments on alaska pollock skin gelatin extraction. J Food Sci, 70 (6), C392-C396. 